\title{
Impact of electrocoagulation on membrane filtration resistance under different proportions of industrial wastewater
}

Guangsheng Qian ${ }^{\mathrm{a}}$, Linlin $\mathrm{Ye}^{\mathrm{b}}$, Liang $\mathrm{Li}^{\mathrm{a}^{*}}$, Xiaomin $\mathrm{Hu}^{\mathrm{a}}$

${ }^{\text {a }}$ School of Resources \& Civil Engineering, Northeastern University, Shenyang 110819, P. R. China

${ }^{\mathrm{b}}$ Department of Chemical Engineering, The University of Melbourne, Melbourne, Victoria 3010, Australia

* Corresponding author: jxij_1104@163.com (Liang Li); Phone: +86 024-83673173

\begin{abstract}
BACKGROUND: The principal purpose of the present work was to explore the mechanism of mitigation membrane fouling in a periodic reversal submerged electro-coagulation membrane bioreactor (SECMBR) with Fe-C electrodes. In this study, membrane resistance and activated sludge performance were compared in a SECMBR and a conventional submerged membrane bioreactor (SMBR).

RESULTS: Adsorption fouling had a strong direct correlation to the soluble microbial products (SMP) and carbohydrates in SMP (SMPc) and had a moderate correlation
\end{abstract}

This is the author manuscript accepted for publication and has undergone full peer review but has not been through the copyediting, typesetting, pagination and proofreading process, which may lead to differences between this version and the Version of Record. Please cite this article as doi: $10.1002 /$ jctb.5670

This article is protected by copyright. All rights reserved. 
with the mixed liquor volatile suspended solids (MLVSS), viscosity and average particle size (APS). SECMBR enhanced the flocculation of suspended sludge, decreased the absolute value of the potential, and maintained microbial activities. With the proportion of oil shale wastewater increasing, soluble microbial products secreted by microorganisms in SECMBR were more than in SMBR.

CONCLUSION: Electrocoagulation technology has the capacity to increase the sludge particle size and decrease the absolute value of the $\mathbb{q}$ potential to alleviate cake layer fouling and total resistance. As the proportion of oil shale wastewater increased, microbial activity in the conventional MBR was inhibited, leading to the less secreted SMP and a lower adsorption fouling rate. The results provide insight into understanding the mechanism of mitigation membrane resistance in SECMBR.

Keywords: Membranes; Fouling; Activated Sludge; Bioreactors; Biotreatment; Environmental Biotechnology

\section{Introduction}

In recent years, membrane bioreactor (MBR) technologies have gained considerable attention due to their potential advantages over conventional biological treatment processes. However, membrane fouling is still the prevalent issue limiting the development of the MBR process ${ }^{1}$. Membrane fouling is the process by which 
particles, colloids and solute molecules cause membrane pores to become smaller or jam by physical or chemical action ${ }^{2}$. Very often, membrane fouling is characterized by a two-phase evolution: a gradual increase of transmembrane pressure (TMP) and a TMP jump, which has been studied by many researchers ${ }^{3}$. In this study, the two-step fouling phenomenon is called adsorption fouling $(\mathrm{Ra})$ and cake layer fouling $(\mathrm{Rc})$, respectively. Adsorption fouling is formed on membrane surfaces and is mainly caused by soluble microbial products, colloids and solutes, etc ${ }^{3}$. Cake layer fouling, consisting of microorganisms, colloids, solutes, and cell debris on the membrane surface $^{4}$, is the product of concentration polarization phenomena and other water conservancy factors that cause the deposits of suspended solids.

There are numerous factors affecting membrane fouling, such as operational conditions, membrane characteristics, sludge properties and mixed liquor characteristics $^{5-7}$. As the cohesive and adhesive matrix of activated sludge, the extracellular polymeric substance (EPS) and soluble microbial product (SMP), which consist of proteins, carbohydrates, lipids, nucleic acids and other polymeric compounds, cause the deterioration of the filterability in the MBR ${ }^{8}$. The EPS is composed of a large number of polymer matrixes surrounding the microorganisms ${ }^{9}$. The excretion of activated sludge, cytolysis and cell wall breakdown products becomes EPS, which consists of polysaccharides, protein and humic substances. The 
SMPs are from microbial metabolic processes and dissolve in water. Many studies have reported that EPS and SMP are acknowledged as major foulants leading to membrane fouling ${ }^{10,11}$, and sludge supernatant containing colloids and solutes play a major role in $\mathrm{it}^{12}$

Hitherto, a new technology of bio-electrocoagulation systems, which combines biological and electrocoagulation treatments, has been rapidly developed to improve nutrients removal and relieve transmembrane pollution ${ }^{13}$. Bani-Melhem et al. found that integrating the EC process with a membrane bioreactor was an effective method for wastewater treatment and for improving membrane filtration ${ }^{14}$. Some researchers studied that external electric fields were capable of enhancing the activities of enzymes and anammox bacteria ${ }^{15,16}$. Additionally, previous studies indicated that the bio-electrocoagulation system with $\mathrm{Fe}-\mathrm{C}$ electrodes was able to increase the biomass and system performance ${ }^{17,18}$. These results revealed that electrocoagulation technology was able to increase the membrane filtration performance as well as the activated sludge performance. However, it is generally known that microorganisms may secrete more soluble organic matter, as their activity increases, which are important components of membrane fouling. This seems to be a paradox. The purpose of this research is to study the mechanism of mitigation membrane fouling by electrocoagulation technology and its application scope. 
Under different wastewater components, the community structure and metabolism of microorganisms change significantly, leading to changes in sludge properties.

Numerous studies indicate that sludge properties have a great influence on membrane fouling ${ }^{19}$. In this research, the activated sludge taken from municipal sewage plants was used as the inoculum sludge. The proportion of oil shale wastewater in influents increased step by step to make the activated sludge gradually adapt to and treat the oil shale wastewater, which belongs to high ammonia nitrogen, low $\mathrm{C} / \mathrm{N}$ ratio and recalcitrant industrial wastewater. During this domestication process, the sludge properties (EPS, SMP, MLVSS, particle size and $₫$ potential, etc.) and different types of membrane filtration resistances were observed to study the influence of electrocoagulation on membrane fouling. Severe changes in sludge properties are conducive for studying the mechanism of electrocoagulation affecting membrane fouling. In addition, the Pearson correlation of sludge properties and membrane fouling was analysed. These findings are significant and meaningful for understanding the mechanism of membrane fouling in the SECMBR. The results obtained in this study lay a foundation for the application scope of bio-electrocoagulation technology and are useful for its development under different conditions, such as industrial wastewater, low temperatures and low $\mathrm{C} / \mathrm{N}$. 


\section{Material and Methods}

\subsection{Experimental setup}

The experiment was established with two identical bioreactors. As shown in Fig. 1, one was a traditional submerged membrane bioreactor (SMBR) and the other one was a submerged electrocoagulation membrane bioreactor (SECMBR). Two lab-scale submerged anoxic/oxic $(\mathrm{A} / \mathrm{O})$ membrane bioreactors consisted of a feed system, two MBRs and two effluent systems. The feed system included a wastewater bucket, two diaphragm pumps (CLY-1205) and two level controllers (TOONE DF-96A). The level controller opened the diaphragm pump as the liquid level was below a certain position. The level controller closed the diaphragm pump when the liquid level rose to another certain position. A hollow fibre curtain-type membrane module (normal pore size: 0.1 $\mu \mathrm{m}$; surface area: $0.2 \mathrm{~m}^{2}$ ) made of polyvinylidene fluoride was submerged inside the aerobic unit. Below the membrane module, there was an aeration device at the bottom of the reactor. The working volume of the whole A/O-MBR reactor was $12 \mathrm{~L}$. The effluents were extracted from the membrane module using a peristaltic pump with an on-off automatic control circuit ( 8 min on- 2 min off). A vacuum gauge was fixed between the peristaltic pump (LongerPump BT100-2J) and membrane module to monitor the TMP. 
In addition to the above components, a pair of Fe-C electrodes $(200 \times 300 \times 3 \mathrm{~mm})$ were set on both sides of the membrane module to construct the submerged electrocoagulation membrane bioreactor (Fig. 1). The distance between electrodes was $10 \mathrm{~cm}$. An autonomous system, which can regulate the current (current: $0.01 \mathrm{~A}$ ) and achieve the electrode periodic reversal (reversal time: $90 \mathrm{~s}$ ) as well as an on-off automatic control circuit (300 s on- $300 \mathrm{~s}$ off), was installed in SECMBR. The autonomous system consisted of a DC power supply (MATRIX MPS-3003L-1), a time relay and a commutator. The operational parameters of the two bioreactors are listed in Table 1.

\subsection{Activated sludge}

Activated sludge was taken from the sludge feed tank, which the returned sludge from the secondary sedimentation pond flowed into, in the Shenyang South wastewater treatment plant. It was aerated at least $24 \mathrm{~h}$. Afterwards, the activated sludge was allocated equally to two bioreactors. The initial MLVSS was 5,496 mg/L; the MLVSS/MLSS was $0.74 ; \mathrm{SV}_{30}$ was $52 \%$ and SVI was $107.26 \mathrm{ml} / \mathrm{g}$.

\subsection{Experimental inoculum and operation}

The influents were mixed with artificial municipal wastewater and the pretreated oil shale wastewater (Table S1). The oil shale wastewater was obtained from the 
wastewater treatment plant of the Fushun shale refinery. After oil separation and two levels of air floatation, pretreated oil shale wastewater flowed into the $\mathrm{A} / \mathrm{O}-\mathrm{MBR}$ reactors. During the first 5 days, the feedwater was simulated domestic wastewater. In the next three stages, the pretreated oil shale wastewater accounted for $5 \%, 15 \%$ and $30 \%$ of the influents, respectively. The main constituent of the artificial wastewater included $\mathrm{C}_{6} \mathrm{H}_{12} \mathrm{O}_{6} \cdot \mathrm{H}_{2} \mathrm{O}, \mathrm{NH}_{4} \mathrm{NO}_{3}, \mathrm{KH}_{2} \mathrm{PO}_{4}, \mathrm{MgSO}_{4} \cdot 7 \mathrm{H}_{2} \mathrm{O}, \mathrm{NaHCO}_{3}, \mathrm{CaCl}_{2}, \mathrm{FeCl}_{3}$, $\mathrm{H}_{3} \mathrm{BO}_{3}, \mathrm{CuSO}_{4} \cdot 5 \mathrm{H}_{2} \mathrm{O}, \mathrm{KI}, \mathrm{MnSO}_{4} \cdot \mathrm{H}_{2} \mathrm{O}, \mathrm{ZnSO}_{4} \cdot 7 \mathrm{H}_{2} \mathrm{O}, \mathrm{C}_{10} \mathrm{H}_{16} \mathrm{~N}_{2} \mathrm{O}_{8}, \mathrm{CoCl}_{2} \cdot 6 \mathrm{H}_{2} \mathrm{O}$ and $\mathrm{Na}_{2} \mathrm{MoO}_{4} \cdot 2 \mathrm{H}_{2} \mathrm{O}$.

The experiment was divided into four stages according to four different concentrations of oil shale wastewater $(0 \%, 5 \%, 15 \%$ and $30 \%)$. The hydraulic retention time (HRT) was 6, 9, 16 and 28 days, respectively. The sludge retention time (SRT) and the reflux ratio were 45 days and $200 \%$, respectively, in the whole process of the experiment (Table S2). The aeration rate in the aerobic tank was maintained at approximately $0.2 \mathrm{~m}^{3} / \mathrm{h}$. During the experiment, the effluents were extracted from the membrane module using a peristaltic pump with an on-off automatic control circuit ( 8 min on-2 min off). When the TMP of either of the membrane modules rose to approximately $0.04 \mathrm{mPa}$, the two membrane modules were cleaned and the cake layer fouling $(\mathrm{Rc})$ and adsorption fouling $(\mathrm{Ra})$ were measured. 


\subsection{Analytical methods}

\subsubsection{Analytical procedures in the sustainable operation}

The determination of $\mathrm{NH}_{4}{ }^{+}-\mathrm{N}, \mathrm{NO}_{2}{ }^{-}-\mathrm{N}, \mathrm{NO}_{3}{ }^{-} \mathrm{N}$ and $\mathrm{COD}$ was performed with a UV1240 spectrophotometer and a HACH DR3900 using the standard method ${ }^{20}$. The mixed liquor suspended solids (MLSS) and mixed liquor volatile suspended solids (MLVSS) were measured based on the gravimetric method. The dissolved oxygen was gauged using a Dissolved Oxygen Meter (HACH LANGE LDO 101). The $\mathrm{pH}$ in the aerobic tanks was kept between 7.5 and 8.5 with the $\mathrm{pH}$ online controller (Lead Fluid BQ50S; ACN LP3000). The sludge particle size and the irons were tested using a laser particle size tester (Malvern 2000, 0.02 - $2000 \mu \mathrm{m}$ ) and a High Dispersion ICP Spectrometer (Prodigy XP), respectively. The potential and the viscosity were measured by a potentiometric readout (Nano ZS90) and a viscometer (SHP NDJ-8S).

\subsubsection{Membrane resistance measurement}

Before the experiment, the two new hollow fibre curtain-type membranes were used to filter pure water at different suction pressures to calculate the membrane's inherent resistance $(\mathrm{Rm})$ by the equation (1).

Cake layer fouling (Rc) and adsorption fouling (Ra): the contaminated membrane 
modules were moved from the bioreactors to another water-filled sink. Then, the membrane modules were cleaned for 10 min under non-pressure with magnetic stirring. The cleaning fluid was discarded and the same volume of distilled water was added again. Afterwards, the contaminated membrane was used to filter pure water at the same pressure, and then the adsorption fouling and calculated cake layer fouling were obtained by equations $(2)^{21}$ and (3).

$$
\begin{aligned}
& R m=\frac{\Delta P}{\mu_{0} J} \times 3600, \\
& R=\frac{\Delta P}{\mu J} \times 3600, \\
& R c=R-R \mathrm{~m}-R a
\end{aligned}
$$

where $\mathrm{Rm}$ is the membrane inherent resistance $\left(\mathrm{m}^{-1}\right)$; Rc is the cake layer resistance $\left(\mathrm{m}^{-1}\right)$; $\mathrm{Ra}$ is the adsorption resistance $\left(\mathrm{m}^{-1}\right) ; \mathrm{R}$ is total resistance $\left(\mathrm{m}^{-1}\right) ; " \mathrm{P}$ is the trans-membrane pressure $(\mathrm{Pa}) ; \mu_{0}$ and $\mu$ are the pure water viscosity and the mixture viscosity $\left(\mathrm{Pa}{ }^{*} \mathrm{~s}\right)$, respectively; and $\mathrm{J}_{0}$ is the instantaneous flux $\left(\mathrm{m}^{3} /\left(\mathrm{m}^{2} \mathrm{~h}\right)\right)$.

The data used for the statistical analyses were generated from two lab-scale systems (SMBR and SECMBR). Statistical analyses were performed using Statistical Product and Service Solutions (SPSS).

$$
R^{2}=\frac{\sum(X-\bar{X})(Y-\bar{Y})}{\sqrt{\sum(X-\bar{X})^{2} \sum(Y-\bar{Y})^{2}}}
$$


where $\mathrm{X}$ and $\mathrm{Y}$ are a sample of paired data, and $*$ and $¥$ are the mean.

The Pearson's product momentum correlation of sludge properties and membrane fouling was tested by statistical analysis. The Pearson product momentum correlation coefficient $\left(\mathrm{R}^{2}\right)$ was used for the linear estimation of the two parameters' linear correlation direction and strength. In the study, the correlation coefficient of $\left|R^{2}\right|>0.7$ is considered as a strong correlation; $0.4 \mathrm{~d}\left|\mathrm{R}^{2}\right| \mathrm{d} 0.7$ is moderate; and $\left|\mathrm{R}^{2}\right|<0.4$ is a weak correlation $^{22}$.

\subsubsection{EPS and SMP}

In this research, proteins (EPSp, SMPp) and carbohydrates (EPSc, SMPc) were considered the main components of the EPS and $\mathrm{SMP}^{8,10,23}$.

\subsubsection{SMP}

Ten millilitres of the activated sludge mixture were collected in the middle of two reactors every three days. The samples were centrifuged at $6,000 \mathrm{r} / \mathrm{min}$ for $10 \mathrm{~min}$. Afterwards, the supernatants were filtrated using the $0.45-\mu \mathrm{m}$ filter membrane. The polysaccharides and protein in the filtrated liquid were measured using anthrone colorimetry and the Coomassie Brilliant Blue Method, respectively. The SMP concentration was based on the sum of these polysaccharides and proteins. 


\subsubsection{EPS}

After being filtrated, the surplus supernatants were discarded. The retained sediments were washed 3 times, and then $10 \mathrm{ml}$ of distilled water were added. The samples were put in an $80^{\circ} \mathrm{C}$ constant temperature water bath for $45 \mathrm{~min}$ before the test tubes were centrifuged at a speed of 10,000 r/min for $20 \mathrm{~min}$. Finally, the mixtures were filtrated using the $0.45-\mu \mathrm{m}$ filter membranes, and the polysaccharides and proteins in this filtrate were analysed to obtain the EPS.

\subsubsection{Enzyme activity test}

The sludge mixture samples were collected from two reactors in the middle of two lab-scale reactors. After the samples were centrifuged at a speed of $6,000 \mathrm{r} / \mathrm{min}$ for 5 min, the supernatants were discarded. The dehydrogenase in activated sludge was measured using the ELIASA Kits 48T (Dehydrogenase Kit). First, the homogenate of samples was centrifuged, and then the supernatants were extracted. Standard substances and the samples were added to the enzyme standard plate, and then the standard plate was sealed using microplate sealers for $30 \mathrm{~min}$ at $37^{\circ} \mathrm{C}$. Next, the enzyme standard reagents were added for $30 \mathrm{~min}$ at $37^{\circ} \mathrm{C}$ after the enzyme standard plate was washed 5 times by a washing machine (Thermo Labsystems, AC8). Third, the enzyme standard plate was washed 5 times again, and the chromogenic agent was added at $37^{\circ} \mathrm{C}$ for $10 \mathrm{~min}$ under dark reaction. Finally, the termination liquids were 
added and the OD values of each hole were tested using the ELIASA (Labsystems Multiskan MS, 352) in 15 min.

\section{Results and discussion}

\subsection{Pollutant removal and membrane fouling in two bioreactors}

\subsubsection{Pollutant removal}

The influent concentrations and treatment rate of the $\mathrm{COD}$ and $\mathrm{NH}_{4}{ }^{+}-\mathrm{N}$ are listed in Table 2. During the first 5 days, the feed water was $100 \%$ artificial wastewater.

During days $6-31,5 \%$ of oil shale wastewater and $95 \%$ of the simulated domestic wastewater constituted the inlet water. Between days 32 and 64, the proportion of oil shale wastewater to artificial wastewater was 3:17. After day 65 , the pretreated oil shale wastewater accounted for $30 \%$ of the influents.

As shown in Table 2, in stage I, the COD and $\mathrm{NH}_{4}{ }^{+}-\mathrm{N}$ concentration in the influent were $391.24-446.57$ and $18.14-22.97 \mathrm{mg} / \mathrm{L}$, respectively, in the two bioreactors. In stage IV, the COD and $\mathrm{NH}_{4}{ }^{+}-\mathrm{N}$ concentration in the influent rose to 1533.83-1797.32 $\mathrm{mg} / \mathrm{L}$ and $97.64-120.23 \mathrm{mg} / \mathrm{L}$, respectively. During the 221-day operation, the COD average removal rate in SMBR and SECMBR decreased from $92.71 \%$ and $93.11 \%$ to $63.11 \%$ and $71.55 \%$, respectively. Similarly, the $\mathrm{NH}_{4}{ }^{+}-\mathrm{N}$ average removal rate in 
SMBR and SECMBR decreased from $91.48 \%$ and $95.37 \%$ in stage I to $44.31 \%$ and $59.09 \%$ in stage IV, respectively. Additionally, the dehydrogenase activity in SMBR and SECMBR decreased from 0.75 and 0.81 to 0.45 and 0.68 , respectively. (Table S3).

The toxicity of the oil wastewater exerted a huge negative influence on the sludge performance. When the oil shale wastewater concentration was equal to or less than $15 \%$ of the influents (stages I-III), the sludge performance in the two reactors was not bad. With the concentration of oil shale wastewater increasing, the gap of COD and $\mathrm{NH}_{4}{ }^{+}-\mathrm{N}$ removal rate between two MBRs widened in stage IV. These values demonstrated that the electrocoagulation was able to enhance the activated performances. This phenomenon was further confirmed by the increase in the gaps of dehydrogenase activity and MLVSS. Dehydrogenase is responsible for the biological oxidation of organic compounds ${ }^{24}$, and its activity can assess the protons catalysed by intermediate products ${ }^{25}$. Some studies indicated that electric field and irons were able to enhance dehydrogenase activity ${ }^{18,26}$. Additionally, previous research showed that electrocoagulation has the capability to increase the relative abundances of nitrogen removal microorganisms to improve the nitrogen removal performance ${ }^{17,27}$. The results indicated the electrocoagulation was capable of maintaining microbial activity when the proportion of industrial wastewater increased in the influents. 


\subsubsection{Membrane fouling}

Fig. 2 shows the membrane fouling with the progression of the running time. The membrane fouling in stages I-III and IV is shown in Figs. 2A and B, respectively. The two membrane modules were cleaned simultaneously when the TMP of either membrane modules rose to approximately $0.04 \mathrm{mPa}$.

As shown in Fig. 2A, the total resistance (R) of the SMBR reached approximately $11.5 \times 10^{12} \mathrm{~m}^{-1}$, while that of the SECMBR only reached approximately $7.5 \times 10^{12} \mathrm{~m}^{-1}$. In addition, the membrane fouling rate of the cake layer fouling $(\mathrm{Rc})$ and adsorption fouling $(\mathrm{Ra})$ were measured and calculated. The slope $(\mathrm{K})$ of the fitting line was considered as the membrane fouling rate (Fig. 2A). For Ra, the $\mathrm{K}_{\mathrm{SMBR}}$ was 0.1898 , 0.1338, 0.1127 and 0.1090 , and the corresponding $\mathrm{K}_{\mathrm{SECMBR}}$ was $0.1285,0.0817,0.084$ and 0.0818 . For Rc, the $\mathrm{K}_{\mathrm{SMBR}}$ was $1.6537,2.0121,1.1682$ and 1.6313, and the corresponding $\mathrm{K}_{\mathrm{SECMBR}}$ was $1.3699,1.3409,1.0012$ and 1.1816.

When the proportion of oil shale wastewater was $30 \%$, the membrane fouling in the fourth stage was shown in Fig. 2B. For R, similar to the former three stages, as the $\mathrm{R}$ in the SMBR reached approximately $12 \times 10^{12} \mathrm{~m}^{-1}$, it reached $8 \times 10^{12}-10 \times 10^{12} \mathrm{~m}^{-1}$ per cycle in stage IV in the SECMBR. For Ra, the K in the SMBR was 0.0721, 0.0632, 0.0489, 0.0331 and 0.0393, whereas it was $0.0690,0.0723,0.0708,0.0742$ and 0.0714 , correspondingly, in the SECMBR. For Rc, the K in the SMBR was 0.8076, 0.7997, 
0.7760, 0.7607 and 0.7573 , and it was $0.4942,0.4832,0.4775,0.4697$ and 0.4223 , correspondingly, in the SECMBR.

In the first three stages, both the adsorption fouling rate and cake layer fouling rate in the SECMBR were much less than those in the SMBR, which revealed that electrocoagulation was capable of effectively reducing the membrane resistance. The results indicated that electrocoagulation may increase the coagulation and sedimentation of suspended sludge and SMP, resulting in the increase of the size of granules and the mitigation of membrane fouling. Similar to the first three stages, the $\mathrm{R}$ and $\mathrm{Rc}$ in the SMBR were higher than those in the SECMBR in stage IV. However, unlike the former three stages, the most Ra in the SMBR was lower than that in the SECMBR (especially after 90 days). Table 4 indicates that the Ra had a significant impact on the $\operatorname{SMP}\left(\mathrm{R}_{\mathrm{SMBR}}^{2}=0.8057, \mathrm{R}_{\mathrm{SECMBR}}^{2}=0.8502\right)$ and $\mathrm{SMPc}\left(\mathrm{R}_{\mathrm{SMBR}}^{2}=0.8832\right.$, $\left.\mathrm{R}_{\text {SECMBR }}^{2}=0.8948\right)$. The SMP, containing small compounds derived from the original substrate and representing soluble $\mathrm{EPS}^{28}$, was able to interact directly with the membrane. Some researchers also argued that the adsorption fouling or gel layer was mainly caused by the SMP and solutes ${ }^{21}$. Additionally, some researchers found that the polysaccharide was more easily attached to the membrane surface, and the inner mediate fouling layer contained a high polysaccharide concentration ${ }^{8,29}$, which was in line with the calculation of the correlation (Table 4). As shown in Figs. 3B and 4B, the 
SMP and SMPc concentrations in the SMBR were less than in the SECMBR in stage IV (especially after 90 days), which may result in the fact that the rate of the Ra in the SMBR was slower than that in the SECMBR.

Over the 221-day period, the proportion of Rc in the total resistance was $71.32 \%-82.51 \%$ and $80.46 \%-85.12 \%$ in the SECMBR and SMBR, respectively. The proportion of the $\mathrm{Ra}$ in the total resistance was $13.87 \%-25.13 \%$ and $11.90 \%-16.05 \%$ in the SECMBR and SMBR, respectively. These values demonstrated that the Rc was more dominant in the two bioreactors. Although the SECMBR increased the adsorption fouling rate, its total resistance was still lower than the SMBR in stage IV.

\subsection{Effect of electrocoagulation on sludge properties}

It is known that sludge properties in MBRs have a great influence on membrane fouling. The EPS and SMP can bring about the deterioration of filterability in the $\mathrm{MBR}^{8}$. The main components of the SMP and EPS are carbohydrates, protein and humus $^{30,31}$, and carbohydrates and proteins also play an important role in membrane fouling ${ }^{32}$. Additionally, some studies show that viscosity has ties to MLVSS and

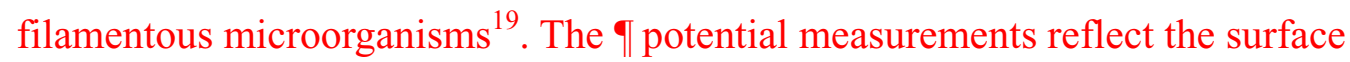
charge of the sludge flocs and particles ${ }^{13}$. The particle size distribution indicates the size of dissolved organic substances and colloids ${ }^{33}$. Small substances are able to block 
membrane pores and form the cake layer. Thus, the impact of electrocoagulation on sludge properties was analysed in detail.

\subsubsection{EPS and SMP}

For EPS and EPSc, these concentrations in two bioreactors showed an increase tread in stages I-III and then decreased in stage IV (Figs. 3A and 4A). From the statistical analysis (Table S4), the EPS and EPSc in the SMBR were higher than in the SECMBR over the operation period. For SMP and SMPc, the SMP in the SMBR showed an increase in stages I-III, and then dropped to approximately $23 \mathrm{mg} / \mathrm{L}$, whereas the chance of the SMP in the SECMBR was not obvious (Fig. 3B). The tendency of the SMPc in two MBRs was similar to the SMP (Fig. 4B). Compared to EPS, the SMP and SMPc in the SMBR were lower than that in the SECMBR in stage IV based on the statistical analysis.

The pollution mechanism of the SMP is that small organic molecules are adsorbed on the membrane holes, causing the irreversible membrane fouling, and macromolecular organic matter mainly are attached on the membrane surface, forming a gel layer ${ }^{34,35}$. Table 4 indicated that the SMP and SMPc had a strong correlation to Ra, which was in line with some studies ${ }^{8,29}$. The SMP and SMPc in the SMBR were higher than in the SECMBR in stages I-III, but they were lower in the SMBR in stage IV (Figs. 3B and 
4B). The toxicity of feed wastewater exerted a great negative impact on the sludge performance. When the oil shale wastewater percentage was equal to or less than $15 \%$ in influents (stages I-III), the performances of the SMBR and SECMBR were not bad, and the gap between the two reactors was not very large (Tables 2 and S3, and Fig. 5). The electrocoagulation caused the suspended substance and SMP coagulated, resulting in the lower SMP in the SECMBR in stages I-III. Nevertheless, 30\% of the oil shale wastewater proportion in influents caused an inhibition of microbial metabolism in the SMBR, which led to less of the SMP secreted by activated sludge. Compared to the SMBR, the application of electrocoagulation in the SECMBR maintained the sludge performance during stage IV, and the SMP and SMPc showed little variation with the proportion of oil shale wastewater increasing. This was the main reason for the increase of the adsorption fouling rate in the SECMBR during stage IV.

Compared to the SMP, the EPS provides sludge floc adhesion to the membrane due to the high molecular weight of the surface and the multi-branch structure and huge specific surface area of the EPS. Yu, Graham, Yang, Zhou and Campos ${ }^{36}$ reported that the higher EPS concentration was a cause of the greater external membrane fouling. Table 4 showed that EPS had a strong correlation with Rc, which was also mentioned by some authors ${ }^{37,38}$. The electrocoagulation device dissolved iron ions, 
causing the suspended EPS to coagulate and a lower EPS concentration in the middle of SECMBR. Over the 221-day period, EPS and EPSc in the SMBR were higher, resulting in a stronger Rc in the SMBR. Some studies showed that the EPS was the complex high-molecular weight mixture and could be produced from the cell lysis $\operatorname{processes}^{38}$. As the proportion of oil shale wastewater increased, the sludge performance declined and more microorganisms died in the conventional MBR, which may cause the EPS to still have been sustained at a high level.

\subsubsection{MLVSS and viscosity}

Fig. 5 shows the MLVSS in the two reactors. The MLVSS in two MBRs was approximately 5,500 $\mathrm{mg} / \mathrm{L}$ initially, and then showed a decreasing trend. They dropped to $2,412.4$ and $3,575.6 \mathrm{mg} / \mathrm{L}$ in stage IV in the SMBR and SECMBR, respectively. With the proportion of oil shale wastewater increasing in the influents, the gap of MLVSS between the two bioreactors widened. Additionally, from the statistical analysis, the sludge viscosity in the SECMBR was lower than that in the SMBR during the first three stages, but it was higher in the SECMBR in stage IV (Table 3).

The electrocoagulation device can dissolve iron ions. Iron is the active centre of some oxidases and is an essential element for microorganisms ${ }^{39,40}$. Appropriate iron ions are able to exert stimulating effects on bacterial metabolism, and affect MLVSS and 
biomass $^{41}$. Dissolved iron ions enhanced the microbial activity, resulting in higher MLVSS concentrations in the SECMBR. Some studies have reported that filamentous microorganisms and soluble substances play an important role in sludge viscosity ${ }^{42}$. In this research, the toxicity of oil shale wastewater in the influent greatly inhibited bacterial metabolism and decreased the number of filamentous bacteria, resulting in the overall sludge viscosity in the two reactors not being high. When the oil shale wastewater proportion was low, the electrocoagulation enabled the suspended substance to coagulate, causing the viscosity in the SECMBR to be lower in stages I-III. However, in stage IV, the increased oil shale wastewater led to the microbial metabolism declining sharply and the secretion decreased in the conventional MBR. Compared to the SMBR, electrocoagulation maintained microbial activity, leading to a little variation of viscosity in the SECMBR. This may be the reason that the sludge viscosity in the SMBR was lower than that in the SECMBR during stage IV.

\subsubsection{T potential and particle size}

Fig. 6 shows that the 9 potential was different in the SMBR and SECMBR. Over the 221-day period, the absolute value of the 9 potential in the SMBR was higher than that in the SECMR. The average particle size in the SMBR was 93.16-110.56 $\mu \mathrm{m}$, and in the SECMBR it increased from $106.87 \mu \mathrm{m}$ in stage I to $187.62 \mu \mathrm{m}$ in stage IV

(Table 3). The particle size distributions at the end of each stage are shown in Fig. S1. 
The percentage of fine particles in the SECMBR was lower than that in the SMBR. In addition, the gap of the particle size between the two reactors widened during the experiment.

The application of the Fe-electrocoagulation device dissolved the iron ions, causing the suspended substance and fine particles to coagulate. The lower 9 potential absolute value in the SECMBR indicated that the coagulation process was stronger. It can be concluded that electrocoagulation was able to improve the floc formation and enhance coagulation. That the Pearson correlation between the potential and APS in the $\operatorname{SECMBR}\left(\mathrm{R}_{\text {SECMBR }}^{2}=-0.7856\right)$ was stronger than that in the $\operatorname{SMBR}\left(\mathrm{R}_{\text {SMBR }}^{2}=-0.3211\right)$ can also reflect this phenomena. The results demonstrated that the electrocoagulation

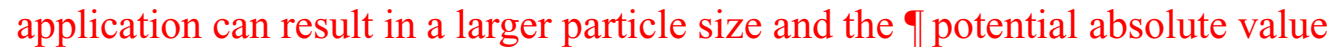
decrease to relieve transmembrane pollution.

\subsection{Correlations between membrane fouling and sludge properties in SECMBR and SMBR}

Over the 221-day period, the Pearson correlation of sludge properties and membrane fouling was tested by statistical analysis. The Pearson correlation coefficient, $\mathrm{R}^{2}$ (Eq. (4)), was used for linear correlations between two parameters. The results of these parameters are shown in Table 4. 
The total fouling $(\mathrm{R})$ in both the SMBR and SECMBR was found to strongly correlate to the cake layer fouling (Rc), adsorption fouling (Ra), EPS, SMP and viscosity, where the correlation between $\mathrm{R}$ and these parameters was almost more than 0.7 . Moreover, the total fouling had a moderate correlation to MLVSS $\left(\mathrm{R}_{\mathrm{SMBR}}^{2}=0.5975\right.$, $\left.\mathrm{R}_{\text {SECMBR }}^{2}=0.5385\right)$ and average particle size $\left(\mathrm{R}_{\text {SMBR }}^{2}=-0.4472, \mathrm{R}_{\text {SECMBR }}^{2}=-0.5370\right)$. For the cake layer fouling $(\mathrm{Rc})$, it had a strong correlation to EPS $\left(\mathrm{R}_{\mathrm{SMBR}}^{2}=0.9403\right.$, $\mathrm{R}_{\text {SECMBR }}^{2}=0.8560$ ). In the SECMBR, the correlation between $\mathrm{Rc}$ and the average particle size (APS) was high $\left(\mathrm{R}_{\text {SECMBR }}^{2}=-0.7107\right)$, whereas this correlation in the SMBR was weak $\left(\mathrm{R}_{\text {SECMBR }}^{2}=-0.2566\right)$. For the adsorption fouling $(\mathrm{Ra})$, the SMP $\left(\mathrm{R}_{\mathrm{SMBR}}^{2}=0.8057, \mathrm{R}_{\mathrm{SECMBR}}^{2}=0.8502\right)$ and $\mathrm{SMPc}\left(\mathrm{R}_{\mathrm{SMBR}}^{2}=0.8832, \mathrm{R}_{\mathrm{SECMBR}}^{2}=0.8948\right)$ had a more significant impact on the Ra than EPS and EPSc. Moreover, the effect of polysaccharides on the Ra was stronger than that of protein in the two reactors, especially in the SMP. Table 4 shows a moderate correlation between MLVSS and Ra. The differences of correlation between the SMBR and SECMBR are analysed in detail below.

EPS and SMP. The EPS in two reactors had a moderate correlation to viscosity $\left(\mathrm{R}_{\text {SMBR }}^{2}=0.5347, \mathrm{R}_{\text {SECMBR }}^{2}=0.4295\right)$, whereas in the SECMBR it had a strong negative correlation to APS $\left(\mathrm{R}_{\mathrm{SMBR}}^{2}=-0.3933, \mathrm{R}_{\mathrm{SECMBR}}^{2}=-0.8649\right)$. Additionally, the correlation between EPSc and 'viscosity and APS' was similar to the EPS. In the SMBR, a 
moderate correlation was obtained between the SMP and APS. In addition to APS, the SMP also had a moderate correlation to MLVSS and 9 in the SECMBR.

The results showed that the Rc and $\mathrm{Ra}$ in both MBRs had a strong correlation to EPS and to SMP and SMPc, respectively. The Rc is the cake layer resistance that belonged to the external fouling layer. Wang, Wu and Tang ${ }^{37}$ found that the EPS had the largest impact on Rc compared to other resistances. Nguyen, $\mathrm{Su}$, Pan and Huang ${ }^{38}$ reported that EPS was one of the main substances of the cake layer. In addition, some studies reported that SMP adsorbed on the block membrane pores and interacted with the membrane surface directly ${ }^{19}$; thus, the SMP played an important role in adsorption membrane fouling (Ra). Compared with the protein, the polysaccharide had a greater adsorption freedom on the surface of the polymer membrane, indicating that the carbohydrate was more easily adsorbed on the common polymer compound membrane ${ }^{10,34}$. Yao, Zhang and $\mathrm{Cui}^{8}$ reported that polysaccharides could be attached to the membrane surface and the inner-middle fouling layer contained a high polysaccharide concentration. Thus, the polysaccharides have a greater impact on adsorptive pollution. These results were consistent with the experimental results. If potential. Table 4 indicates that R, Ra, SMP and SMPc had inverse correlations with the 9 potential in the SECMBR. In this research, the samples of potential were collected from the sludge supernatant around the membrane module; thus, the 1 potential directly reflected the sedimentation of soluble microbial products (SMP). As 
the SMP in the supernatant coagulated, the absolute value of the potential decreased, and then the membrane fouling decreased in the SECMBR. However, the SMBR experienced a different behaviour where the $\$$ potential had a weak correlation to the $\mathrm{R}$ and SMP, indicating that the coagulation process was not obvious in the SMBR. When the absolute value of the 9 potential increased, more negative charges were attached to the sludge, stabilizing the fouling system and preventing the sludge from flocculating.

These findings are in accord with several studies that reported that electric fields changed the 9 potential of mixtures ${ }^{43-45}$, drove a sludge filter cake to leave the membrane surface ${ }^{46}$, and reduced membrane fouling ${ }^{47-49}$. These results show that the electrocoagulation made soluble particles congeal by increasing their attraction force for each other in the SECMBR.

Viscosity, particle size. The impact of viscosity and average particle size on membrane fouling are shown in Table 4. The Pearson correlation analyses showed that viscosity had a moderate correlation to R, Ra, EPS, APS and MLVSS in two bioreactors, which is in accordance with some studies that reported the filamentous microorganisms and soluble substances exerted a huge influence on sludge viscosity ${ }^{42}$. The viscosity was measured using a viscometer (SHP NDJ-8S) that needed to stir the samples, leading to the fact that the bottom EPS and activated sludge were suspended in solution. This may cause the EPS to have a moderate correlation with viscosity.

Fig. S1 shows that as the average particle size increased, the percentage of fine 
particles became smaller. The average particle size could be approximated to represent the sludge particle size distribution at each measurement. In this research, the APS was used to study its Pearson correlation with membrane fouling and other sludge properties. The APS had a moderate correlation with R, SMP and viscosity in two MBRs (Table 4). Comparing the two reactors, a strong Pearson correlation was obtained between APS and 'Rc, EPS and $\uparrow$ potential in the SECMBR, while a weak correlation was obtained between APS and these parameters in the SMBR. It means that electrocoagulation is capable of increasing coagulation and sedimentation of suspended sludge, resulting in the increase of the granule size and the mitigation of membrane fouling.

\section{Conclusions}

The results obtained in this study show that the cake layer fouling contributed up to more than $70 \%$ of the total resistance and was the dominant fouling.

Electrocoagulation technology has the capacity of increasing sludge particle size and decreasing the absolute value of the 9 potential to alleviate cake layer fouling and total resistance. Additionally, it increases the biomass and maintains the microbial activity. The adsorption fouling had a strong direct correlation to the SMP and SMPc, and a moderate correlation with MLVSS and viscosity. As the proportion of oil shale wastewater increased, microbial metabolism in the SMBR was greatly inhibited, leading to a decrease of secreted SMP, viscosity and MLVSS, which was the main 
reason that the rate of $\mathrm{Ra}$ in the SMBR was slower than that in the SECMBR in stage IV.

\section{Acknowledgements}

This work was supported by the Major Science and Technology Program for Water Pollution Control and Treatment (2013ZX07202-010).

\section{References}

1. Babatsouli P, Palogos I, Michalodimitraki E, Costa C and Kalogerakis N, Evaluation of a MBR pilot treating industrial wastewater with a high $\mathrm{COD} / \mathrm{N}$ ratio. J Chem Technol Biot 90: 26-33 (2015).

2. Liang S, Liu C and Song LF, Soluble microbial products in membrane bioreactor operation: Behaviors, characteristics, and fouling potential. Water research 41: 95-101 (2007).

3. Wang ZW, Wu ZC, Yin X and Tian LM, Membrane fouling in a submerged membrane bioreactor (MBR) under sub-critical flux operation: Membrane foulant and gel layer characterization. Journal of Membrane Science $\mathbf{3 2 5}$ : 238-244 (2008).

4. Wang C, Chen WN, Hu QY, Ji M and Gao X, Dynamic fouling behavior and cake layer structure changes in nonwoven membrane bioreactor for bath 
wastewater treatment. Chemical Engineering Journal 264: 462-469 (2015).

5. Drews A, Vocks M, Bracklow U, Iversen V and Kraume M, Does fouling in MBRs depend on SMP? Desalination 231: 141-149 (2008).

6. Trussell RS, Merlo RP, Hermanowicz SW and Jenkins D, The effect of organic loading on process performance and membrane fouling in a submerged membrane bioreactor treating municipal wastewater. Water research 40: 2675-2683 (2006).

7. Aydiner C, Kaya Y, Beril Gönder Z and Vergili I, Evaluation of membrane fouling and flux decline related with mass transport in nanofiltration of tartrazine solution. Journal of Chemical Technology \& Biotechnology $\mathbf{8 5}$ : 1229-1240 (2010).

8. Yao M, Zhang K and Cui L, Characterization of protein-polysaccharide ratios on membrane fouling. Desalination 259: 11-16 (2010).

9. Redmile-Gordon MA, Brookes PC, Evershed RP, Goulding KWT and Hirsch PR, Measuring the soil-microbial interface: Extraction of extracellular polymeric substances (EPS) from soil biofilms. Soil Biol Biochem 72: 163-171 (2014).

10. Rosenberger S, Laabs C, Lesjean B, Gnirss R, Amy G, Jekel M and Schrotter JC, Impact of colloidal and soluble organic material on membrane 
performance in membrane bioreactors for municipal wastewater treatment. Water research 40: 710-720 (2006).

11. Sun FY, Wang XM and Li XY, Visualisation and characterisation of biopolymer clusters in a submerged membrane bioreactor. Journal of Membrane Science 325: 691-697 (2008).

12. Bouhabila E, Ben Aim R and Buisson H, Fouling characterisation in membrane bioreactors. Separation and Purification Technology 22-3: $123-132(2001)$.

13. Hasan SW, Elektorowicz M and Oleszkiewicz JA, Correlations between trans-membrane pressure (TMP) and sludge properties in submerged membrane electro-bioreactor (SMEBR) and conventional membrane bioreactor (MBR). Bioresource Technol 120: 199-205 (2012).

14. Bani-Melhem K and Smith E, Grey water treatment by a continuous process of an electrocoagulation unit and a submerged membrane bioreactor system. Chemical Engineering Journal 198-199: 201-210 (2012).

15. Wang CX, Zhang HL, Ren DJ, Li Q, Zhang SQ and Feng T, Effect of Direct-Current Electric Field on Enzymatic Activity and the Concentration of Laccase. Indian J Microbiol 55: 278-284 (2015).

16. Yin X, Qiao S and Zhou JT, Using electric field to enhance the activity of 
anammox bacteria. Appl Microbiol Biot 99: 6921-6930 (2015).

17. Qian GS, Hu XM, Li L, Ye LL and Lv WJ, Effect of iron ions and electric field on nitrification process in the periodic reversal bio-electrocoagulation system. Bioresource Technol 244: 382-390 (2017).

18. Qian GS, Li L, Hu XM, Yu X and Ye LL, Enhancement of the biodegradability of activated sludge by the electric-coagulation multistage $\mathrm{A} / \mathrm{O}$ membrane bioreactor treating low $\mathrm{C} / \mathrm{N}$ industrial wastewater. Int Biodeter Biodegr 125: 1-12 (2017).

19. Le-Clech P, Chen V and Fane TAG, Fouling in membrane bioreactors used in wastewater treatment. Journal of Membrane Science 284: 17-53 (2006).

20. APHA, Standard Methods for the Examination of Water and Wastewater. American Public Health Association (1998).

21. Wang QY, Wang ZW, Wu ZC, Ma JX and Jiang ZY, Insights into membrane fouling of submerged membrane bioreactors by characterizing different fouling layers formed on membrane surfaces. Chemical Engineering Journal 179: 169-177 (2012).

22. Chen JH, Yu H, Lin M, Mehta RS and Su MY, Background parenchymal enhancement in the contralateral normal breast of patients undergoing neoadjuvant chemotherapy measured by DCE-MRI. Magn Reson Imaging 31: 
1465-1471 (2013).

23. Zuriaga-Agustí E, Bes-Piá A, Mendoza-Roca JA and Alonso-Molina JL, Influence of extraction methods on proteins and carbohydrates analysis from MBR activated sludge flocs in view of improving EPS determination. Separation and Purification Technology 112: 1-10 (2013).

24. Yi XH, Jing DD, Wan JQ, Ma YW and Wang Y, Temporal and spatial variations of contaminant removal, enzyme activities, and microbial community structure in a pilot horizontal subsurface flow constructed wetland purifying industrial runoff. Environ Sci Pollut R 23: 8565-8576 (2016).

25. Kumar AN, Reddy CN and Mohan SV, Biomineralization of azo dye bearing wastewater in periodic discontinuous batch reactor: Effect of microaerophilic conditions on treatment efficiency. Bioresource Technol 188: 56-64 (2015).

26. Li XJ, Wang X, Wan LL, Zhang YY, Li N, Li DS and Zhou QX, Enhanced biodegradation of aged petroleum hydrocarbons in soils by glucose addition in microbial fuel cells. J Chem Technol Biot 91: 267-275 (2016).

27. Qian GS, Ye LL, Li L, Hu XM, Jiang BH and Zhao X, Influence of electric field and iron on the denitrification process from nitrogen-rich wastewater in a periodic reversal bio-electrocoagulation system. Bioresour Technol 258: 
177-186 (2018).

28. Jarusutthirak C and Amy G, Role of Soluble Microbial Products (SMP) in Membrane Fouling and Flux Decline. Environ Sci Technol 40: 969-974 (2006).

29. Le-Clech P, Marselina Y, Ye Y, Stuetz RM and Chen V, Visualisation of polysaccharide fouling on microporous membrane using different characterisation techniques. Journal of Membrane Science 290: 36-45 (2007).

30. Liu YJ, Liu Z, Zhang AN, Chen YP and Wang XC, The role of EPS concentration on membrane fouling control: Comparison analysis of hybrid membrane bioreactor and conventional membrane bioreactor. Desalination 305: 38-43 (2012).

31. Dizge N and Tansel B, Multiparametric investigation of competitive and noncompetitive sorption characteristics of SMP fractions (carbohydrate and protein) on activated carbon. J Hazard Mater 185: 996-1004 (2011).

32. Duan L, Jiang W, Song YH, Xia SQ and Hermanowicz SW, The characteristics of extracellular polymeric substances and soluble microbial products in moving bed biofilm reactor-membrane bioreactor. Bioresource Technol 148: 436-442 (2013).

33. Liu YW, Li X, Yang YL, Ye WL, Ji SY, Ren JW and Zhou ZW, Analysis of 
the major particle-size based foulants responsible for ultrafiltration membrane fouling in polluted raw water. Desalination 347: 191-198 (2014).

34. Rosenberger S, Evenblij H, Tepoele S, Wintgens T and Laabs C, The importance of liquid phase analyses to understand fouling in membrane assisted activated sludge processes—-six case studies of different European research groups. Journal of Membrane Science 263: 113-126 (2005).

35. Yuniarto A, Noor ZZ, Ujang Z, Olsson G, Aris A and Hadibarata T, Bio-fouling reducers for improving the performance of an aerobic submerged membrane bioreactor treating palm oil mill effluent. Desalination 316: 146-153 (2013).

36. Yu WZ, Graham N, Yang YJ, Zhou ZQ and Campos LC, Effect of sludge retention on UF membrane fouling: The significance of sludge crystallization and EPS increase. Water research 83: 319-328 (2015).

37. Wang ZW, Wu ZC and Tang SJ, Extracellular polymeric substances (EPS) properties and their effects on membrane fouling in a submerged membrane bioreactor. Water research 43: 2504-2512 (2009).

38. Nguyen TN, Su YC, Pan JR and Huang C, Comparison of membrane foulants occurred under different sub-critical flux conditions in a membrane bioreactor (MBR). Bioresour Technol 166: 389-394 (2014). 
39. Li HC, Zhou QF, Wu Y, Fu JJ, Wang T and Jiang GB, Effects of waterborne nano-iron on medaka (Oryzias latipes): Antioxidant enzymatic activity, lipid peroxidation and histopathology. Ecotox Environ Safe 72: 684-692 (2009).

40. Xie YK, Dong HR, Zeng GM, Tang L, Jiang Z, Zhang C, Deng JM, Zhang LH and Zhang Y, The interactions between nanoscale zero-valent iron and microbes in the subsurface environment: A review. J Hazard Mater 321: 390-407 (2017).

41. Ma JT, Chen YL, Luo G, Nie JX, Guo ZG, Liu Y and Ma LM, Microbial nitrate removal by waste iron shavings from the biological and catalytic ozonation treated dyeing and finishing wastewater. Amb Express 7 (2017).

42. Chang IS, Le Clech P, Jefferson B and Judd S, Membrane fouling in membrane bioreactors for wastewater treatment. J Environ Eng-Asce 128: 1018-1029 (2002).

43. Bani-Melhem K and Elektorowicz M, Performance of the submerged membrane electro-bioreactor (SMEBR) with iron electrodes for wastewater treatment and fouling reduction. Journal of Membrane Science 379: 434-439 (2011).

44. van der Wouden EJ, Hermes DC, Gardeniers JGE and van den Berg A, Directional flow induced by synchronized longitudinal and zeta-potential 
controlling AC-electrical fields. Lab Chip 6: 1300-1305 (2006).

45. Lubomska $\mathrm{M}$ and Chibowski $\mathrm{E}$, Effect of radio frequency electric fields on the surface free energy and zeta potential of Al2O3. Langmuir 17: 4181-4188 (2001).

46. Jing-Yi HU, Deng HP and Shang R, A study of electrically enhanced crossflow membrane filtration. Industrial Water \& Wastewater (2009).

47. Chen JP, Yang CZ, Zhou JH and Wang XY, Study of the influence of the electric field on membrane flux of a new type of membrane bioreactor. Chemical Engineering Journal 128: 177-180 (2007).

48. Liu LF, Liu JD, Gao B and Yang FL, Minute electric field reduced membrane fouling and improved performance of membrane bioreactor. Separation and Purification Technology 86: 106-112 (2012).

49. Zhang J, Satti A, Chen XG, Xiao K, Sun JY, Yan XX, Liang P, Zhang XY and Huang X, Low-voltage electric field applied into MBR for fouling suppression: Performance and mechanisms. Chemical Engineering Journal 273: $223-230$ (2015).

\section{Appendices}

Table 1 Operational conditions of the MBRs. 
Table 2 Influent concentrations and treatment rate of COD and $\mathrm{NH}_{4}{ }^{+}-\mathrm{N}$ in SECMBR and SMBR. Removal rates are means (standard deviation).

Table 3 Irons, particle size and viscosity concentrations in SECMBR and SMBR.

Data are means (standard deviation).

Table 4 Correlation coefficient between membrane fouling and sludge properties in SECMBR (bold) and SMBR

Fig. 1 Experimental schematic facility diagram of SECMBR and SMBR.

Fig. 2 Variations of membrane resistance of two MBRs in stages I-III (A) and stage IV (B).

Fig. 3 Variations of EPS (A) and SMP (B) in the two MBRs during stable operation.

Fig. 4 Variations of EPSc (A) and SMPc (B) in the two MBRs during stable operation.

Fig. 5 MLVSS concentrations in the two MBRs during stable operation.

Fig. 6 I potentials in SMBR and SECMBR.

Table S1 Main characteristics of oil shale wastewater.

Table S2 Continuous operational process of the MBRs.

Table S3 Dehydrogenase activity in the two MBRs. Data are means (standard 
deviation).

Table S4 The statistical analysis of the main data in two bioreactors. Data are means (standard deviation).

Fig. S1 Sludge particle size distributions in SECMBR and SMBR on days 5, 30, 59 and 209.

Fig. S2 Illustration summarizing the contents of the study. 
Table 1 Operational conditions of the MBRs.

\begin{tabular}{cc}
\hline \multicolumn{2}{c}{ Operational conditions } \\
\hline Volume of the bioreactor \\
HRT & $12 \mathrm{~L}$ \\
SRT & $6-28$ days \\
Mixture reflux rate & 45 days \\
pH & $400 \%$ \\
Current & $7.5-8.5$ \\
On-off automatic control circuit for the effluent pump & 8 min on - 2 min off \\
Reversal time & $0.01 \mathrm{~A}$ \\
On-off automatic control circuit for the DC power supply & $300 \mathrm{~s} \mathrm{on}-300 \mathrm{~s} \mathrm{off}$ \\
Electrode size & $200 \times 300 \times 3 \mathrm{~mm}$ \\
\hline
\end{tabular}

This article is protected by copyright. All rights reserved. 


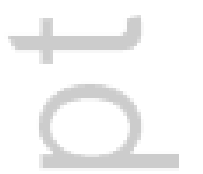

4 
Table 2 Influent concentrations and treatment rate of COD and $\mathrm{NH}_{4}{ }^{+}-\mathrm{N}$ in SECMBR and SMBR. Removal rates are means (standard deviation).

\begin{tabular}{|c|c|c|c|c|c|c|c|c|}
\hline & \multirow{2}{*}{$\begin{array}{l}\text { Phase } \\
\text { (d) }\end{array}$} & \multirow{2}{*}{$\begin{array}{c}\text { Inf. COD } \\
(\mathrm{mg} / \mathrm{L})\end{array}$} & \multirow{2}{*}{$\begin{array}{c}\text { Inf. } \mathrm{NH}_{4}{ }^{+}-\mathrm{N} \\
(\mathrm{mg} / \mathrm{L})\end{array}$} & \multirow{2}{*}{$\begin{array}{c}\text { HRT } \\
\text { (h) }\end{array}$} & \multicolumn{2}{|c|}{ COD removal rate $(\%)$} & \multicolumn{2}{|c|}{$\mathrm{NH}_{4}{ }^{+}-\mathrm{N}$ removal rate $(\%)$} \\
\hline & & & & & SMBR & SECMBR & SMBR & SECMBR \\
\hline Stage I & $1-5^{\mathrm{a}}$ & $391.24-446.57$ & $18.14-22.97$ & 6 & $\begin{array}{l}92.71 \\
(5.64)\end{array}$ & $\begin{array}{l}93.11 \\
(4.91)\end{array}$ & $\begin{array}{l}91.48 \\
(5.37)\end{array}$ & $\begin{array}{l}95.37 \\
(5.11)\end{array}$ \\
\hline Stage II & $6-31^{b}$ & $756.66-816.74$ & $39.27-64.24$ & 9 & $\begin{array}{l}81.24 \\
(7.65)\end{array}$ & $\begin{array}{l}85.39 \\
(8.07)\end{array}$ & $\begin{array}{l}78.35 \\
(9.47)\end{array}$ & $\begin{array}{l}86.96 \\
(8.24)\end{array}$ \\
\hline Stage III & $32-64^{\mathrm{c}}$ & 1056.71-1197.18 & $74.64-92.57$ & 16 & $\begin{array}{l}73.64 \\
(9.61)\end{array}$ & $\begin{array}{l}78.69 \\
(9.36)\end{array}$ & $\begin{array}{l}61.42 \\
(9.44)\end{array}$ & $\begin{array}{l}73.12 \\
(9.63)\end{array}$ \\
\hline Stage IV & $65-221^{d}$ & $1533.83-1797.32$ & $97.64-120.23$ & 28 & $\begin{array}{c}63.11 \\
(11.67)\end{array}$ & $\begin{array}{l}71.55 \\
(9.87)\end{array}$ & $\begin{array}{l}44.31 \\
(8.76)\end{array}$ & $\begin{array}{l}59.09 \\
(8.10)\end{array}$ \\
\hline
\end{tabular}

${ }^{\mathrm{a}} 0 \%$ of oil shale wastewater in influents

${ }^{\mathrm{b}} 5 \%$ of oil shale wastewater in influents

c $15 \%$ of oil shale wastewater in influents

d $30 \%$ of oil shale wastewater in influents 
Table 3 Irons, particle size and viscosity concentrations in SECMBR and SMBR.

Data are means (standard deviation).

\begin{tabular}{ccccccc}
\hline \multirow{2}{*}{ Stage } & \multicolumn{2}{c}{ Irons $(\mathbf{m g} / \mathbf{L})$} & \multicolumn{3}{c}{ Particle size $(\boldsymbol{\mu m})$} & \multicolumn{2}{c}{ Viscosity $(\mathbf{m P a} \mathbf{s})$} \\
& SMBR & SECMBR & SMBR & SECMBR & SMBR & SECMBR \\
\hline \multirow{2}{*}{ Stage I $^{\text {a }}$} & 0.34 & 0.78 & 93.16 & 106.87 & 6.91 & 5.64 \\
& $(0.045)$ & $(0.092)$ & $(6.87)$ & $(10.62)$ & $(0.75)$ & $(0.65)$ \\
Stage II $^{\mathbf{b}}$ & 0.32 & 2.21 & 100.47 & 119.22 & 6.25 & 5.45 \\
& $(0.041)$ & $(0.34)$ & $(7.68)$ & $(16.14)$ & $(0.67)$ & $(1.15)$ \\
Stage III $^{\mathbf{c}}$ & 0.41 & 4.16 & 97.64 & 146.16 & 6.78 & 5.27 \\
& $(0.057)$ & $(0.59)$ & $(6.22)$ & $(21.41)$ & $(0.66)$ & $(1.04)$ \\
Stage IV $^{\mathbf{d}}$ & 0.28 & 8.23 & 110.56 & 187.62 & 5.09 & 5.11 \\
& $(0.034)$ & $(1.17)$ & $(7.34)$ & $(29.92)$ & $(1.07)$ & $(0.94)$ \\
\hline
\end{tabular}

${ }^{\mathrm{a}} 0 \%$ of oil shale wastewater in influents

b $5 \%$ of oil shale wastewater in influents

c $15 \%$ of oil shale wastewater in influents

d $30 \%$ of oil shale wastewater in influents 
Table 4 Correlation coefficient between membrane fouling and sludge properties in SECMBR (bold) and SMBR.

\begin{tabular}{|c|c|c|c|c|c|c|c|c|c|c|c|c|c|}
\hline & $\begin{array}{c}\mathrm{R} \\
10^{12} \mathrm{~m}^{-1}\end{array}$ & $\begin{array}{c}\mathrm{Rc} \\
10^{12} \mathrm{~m}^{-1}\end{array}$ & $\begin{array}{c}\mathrm{Ra} \\
10^{12} \mathrm{~m}^{-1}\end{array}$ & $\begin{array}{r}\text { EPS } \\
\mathrm{mg} / \mathrm{L}\end{array}$ & $\begin{array}{l}\text { EPSc } \\
\mathrm{mg} / \mathrm{L}\end{array}$ & $\begin{array}{l}\text { EPSp } \\
\mathrm{mg} / \mathrm{L}\end{array}$ & $\begin{array}{l}\text { SMP } \\
\mathrm{mg} / \mathrm{L}\end{array}$ & $\begin{array}{l}\text { SMPc } \\
\mathrm{mg} / \mathrm{L}\end{array}$ & $\begin{array}{l}\text { SMPp } \\
\mathrm{mg} / \mathrm{L}\end{array}$ & $\begin{array}{c}\text { MLVSS } \\
\mathrm{mg} / \mathrm{L}\end{array}$ & $\begin{array}{c}\text { I } \\
\mathrm{mV}\end{array}$ & $\begin{array}{l}\text { Visc. } \\
\text { mPa.s }\end{array}$ & $\begin{array}{c}\text { APS } \\
\mu \mathrm{m}\end{array}$ \\
\hline $\mathrm{R}$ & 1 & & & & & & & & & & & & \\
\hline \multirow[t]{2}{*}{$\mathrm{Rc}$} & 0.9245 & 1 & & & & & & & & & & & \\
\hline & 0.8314 & 1 & & & & & & & & & & & \\
\hline $\mathrm{Ra}$ & 0.7258 & 0.2594 & 1 & & & & & & & & & & \\
\hline \multirow[t]{2}{*}{ EPS } & 0.8014 & 0.9403 & 0.3203 & 1 & & & & & & & & & \\
\hline & 0.7495 & 0.8560 & 0.2846 & 1 & & & & & & & & & \\
\hline \multirow[t]{2}{*}{ EPSc } & 0.7698 & 0.7804 & 0.4934 & 0.7851 & 1 & & & & & & & & \\
\hline & 0.6159 & 0.6435 & 0.4757 & 0.6529 & 1 & & & & & & & & \\
\hline SMP & 0.7045 & 0.3928 & 0.8502 & 0.0294 & 0.0209 & 0.0236 & 1 & & & & & & \\
\hline \multirow[t]{2}{*}{ SMPc } & 0.7249 & 0.3796 & 0.8832 & 0.3433 & 0.2457 & 0.2760 & 0.7056 & 1 & & & & & \\
\hline & 0.6266 & 0.2007 & 0.8948 & 0.0002 & 0.0001 & -0.0062 & 0.6933 & 1 & & & & & \\
\hline \multirow[t]{2}{*}{ SMPp } & 0.5319 & 0.2919 & 0.2666 & 0.2051 & 0.1257 & 0.1908 & 0.4983 & 0.2061 & 1 & & & & \\
\hline & 0.6065 & 0.3286 & 0.3991 & 0.0326 & 0.0140 & 0.0440 & 0.5289 & -0.1876 & 1 & & & & \\
\hline \multirow[t]{2}{*}{ MLVSS } & 0.5975 & 0.3530 & 0.6512 & 0.1617 & 0.1494 & 0.1368 & -0.0732 & 0.0299 & -0.1813 & 1 & & & \\
\hline & 0.5385 & 0.2190 & 0.4412 & 0.3320 & 0.3022 & -0.0113 & 0.4954 & 0.4709 & 0.2464 & 1 & & & \\
\hline \multirow[t]{2}{*}{ 【 } & -0.2131 & -0.1765 & -0.1813 & -0.0032 & -0.0011 & -0.0026 & -0.1912 & -0.1814 & -0.0735 & -0.1342 & 1 & & \\
\hline & -0.5162 & -0.2063 & -0.6365 & -0.0156 & -0.0217 & -0.0140 & -0.4652 & -0.4247 & -0.0206 & -0.0297 & 1 & & \\
\hline
\end{tabular}

This article is protected by copyright. All rights reserved. 


\begin{tabular}{cccccccccccccc} 
Visc. & 0.6726 & 0.3017 & 0.5113 & 0.5347 & 0.3443 & 0.4391 & 0.3489 & 0.3072 & 0.1176 & 0.4667 & -0.2287 & 1 & \\
& $\mathbf{0 . 7 7 8 9}$ & $\mathbf{0 . 4 7 5 1}$ & $\mathbf{0 . 6 1 8 2}$ & $\mathbf{0 . 4 2 5 9}$ & $\mathbf{0 . 4 3 2 9}$ & $\mathbf{0 . 1 5 2 7}$ & $\mathbf{0 . 3 3 1 6}$ & $\mathbf{0 . 2 5 9 2}$ & $\mathbf{0 . 2 5 5 5}$ & $\mathbf{0 . 6 8 7 9}$ & $\mathbf{- 0 . 1 2 4 6}$ & $\mathbf{1}$ & \\
APS & -0.4472 & -0.2566 & -0.3269 & -0.3933 & -0.3669 & -0.1917 & -0.5021 & -0.3637 & -0.5794 & 0.2656 & -0.3211 & -4.6570 & 1 \\
& $\mathbf{- 0 . 5 3 7 0}$ & $\mathbf{- 0 . 7 1 0 7}$ & $\mathbf{- 0 . 6 4 5 9}$ & $\mathbf{- 0 . 8 6 4 9}$ & $\mathbf{- 0 . 6 5 7 2}$ & $\mathbf{- 0 . 5 3 3 8}$ & $\mathbf{- 0 . 6 5 9 7}$ & $\mathbf{- 0 . 5 3 2 4}$ & $\mathbf{- 0 . 7 4 1 8}$ & $\mathbf{0 . 3 9 9 6}$ & $\mathbf{- 0 . 7 8 5 6}$ & $\mathbf{- 6 . 3 3 8 7}$ & $\mathbf{1}$ \\
\hline
\end{tabular}

Note: SECMBR results are shown in bold 
Fig. 1 Experimental schematic facility diagram of SECMBR and SMBR.

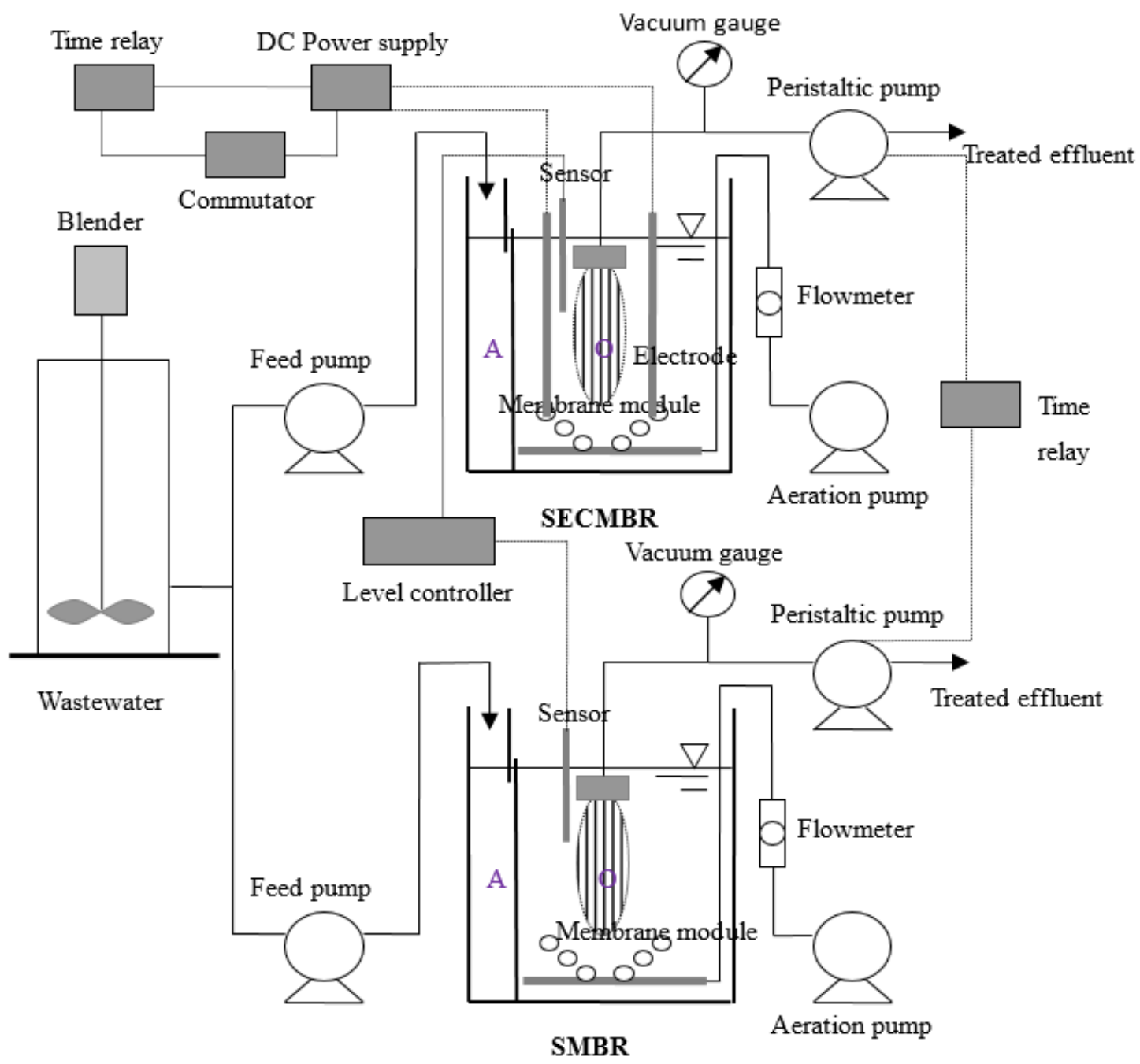

This article is protected by copyright. All rights reserved. 
Fig. 2 Variations of membrane resistance of two MBRs in stages I-III (A) and stage IV (B).

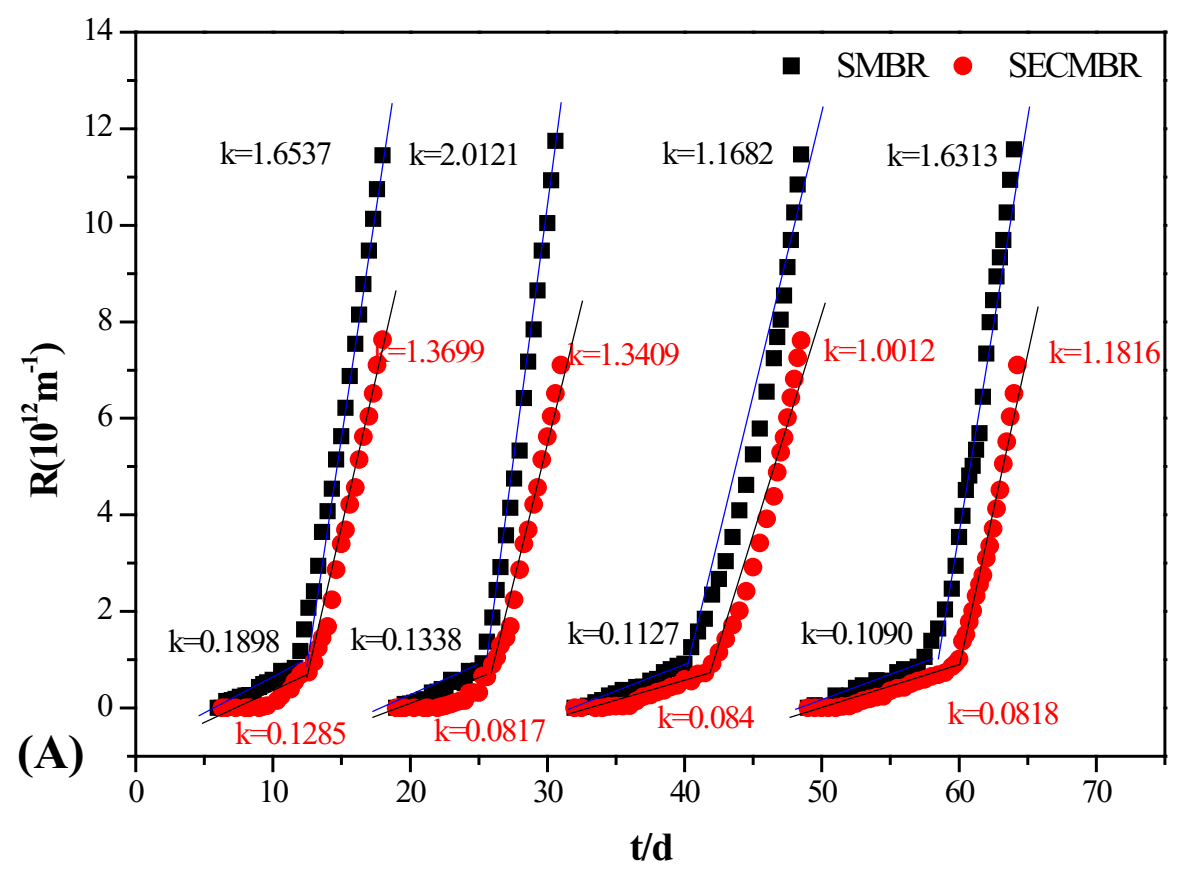

This article is protected by copyright. All rights reserved. 


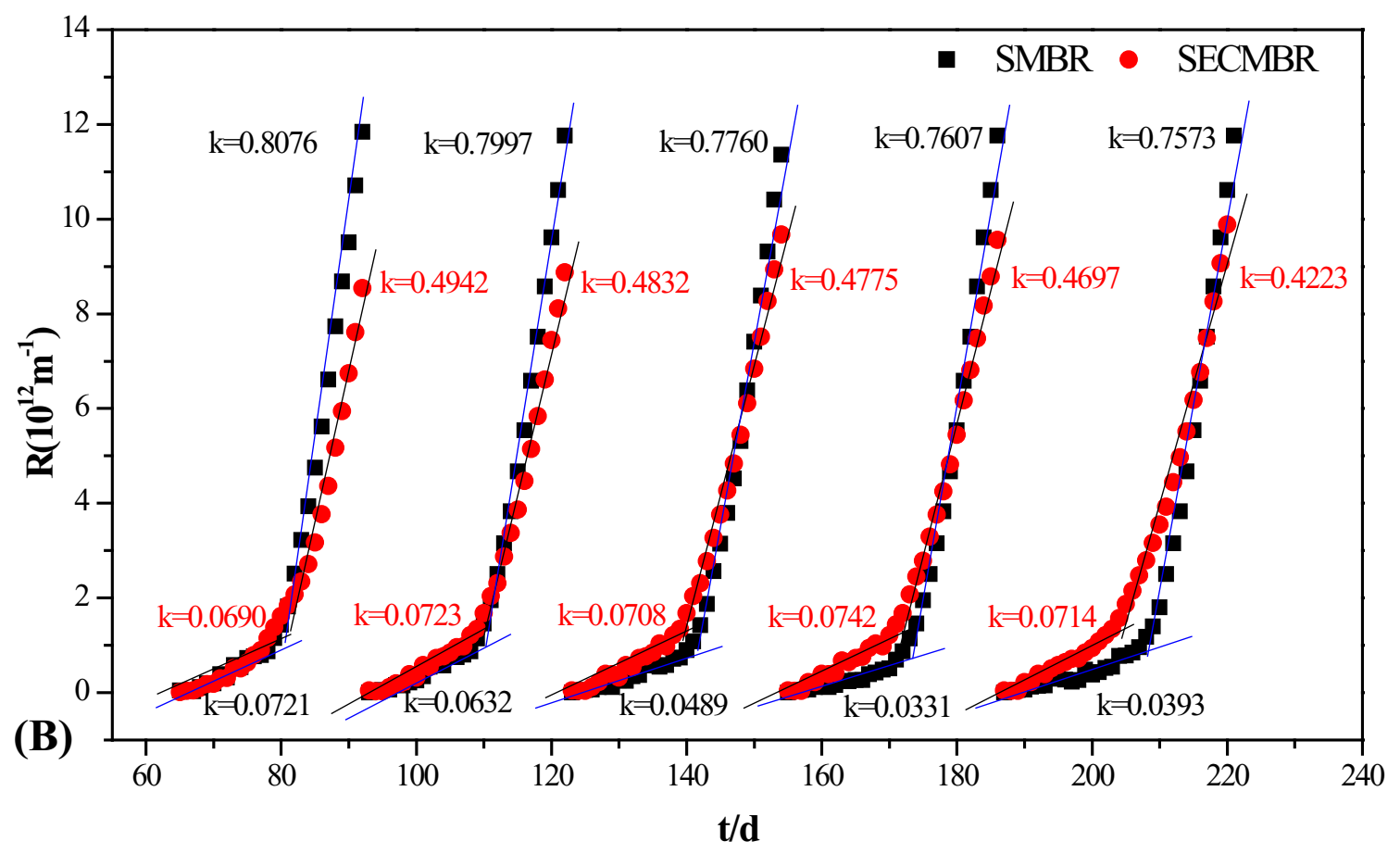

Fig. 3 Variations of EPS (A) and SMP (B) in the two MBRs during stable operation.

This article is protected by copyright. All rights reserved. 


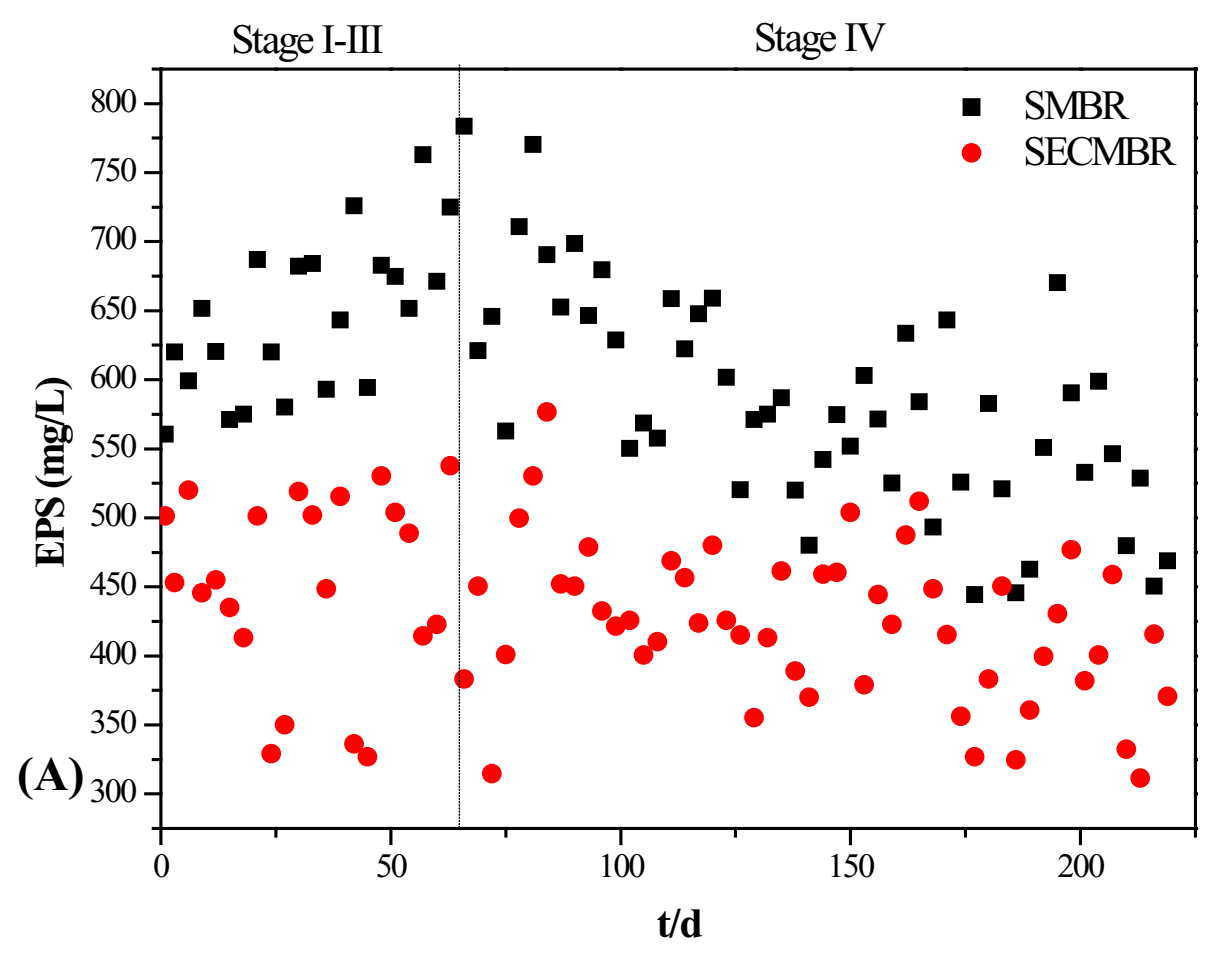

(B)

This article is protected by copyright. All rights reserved. 


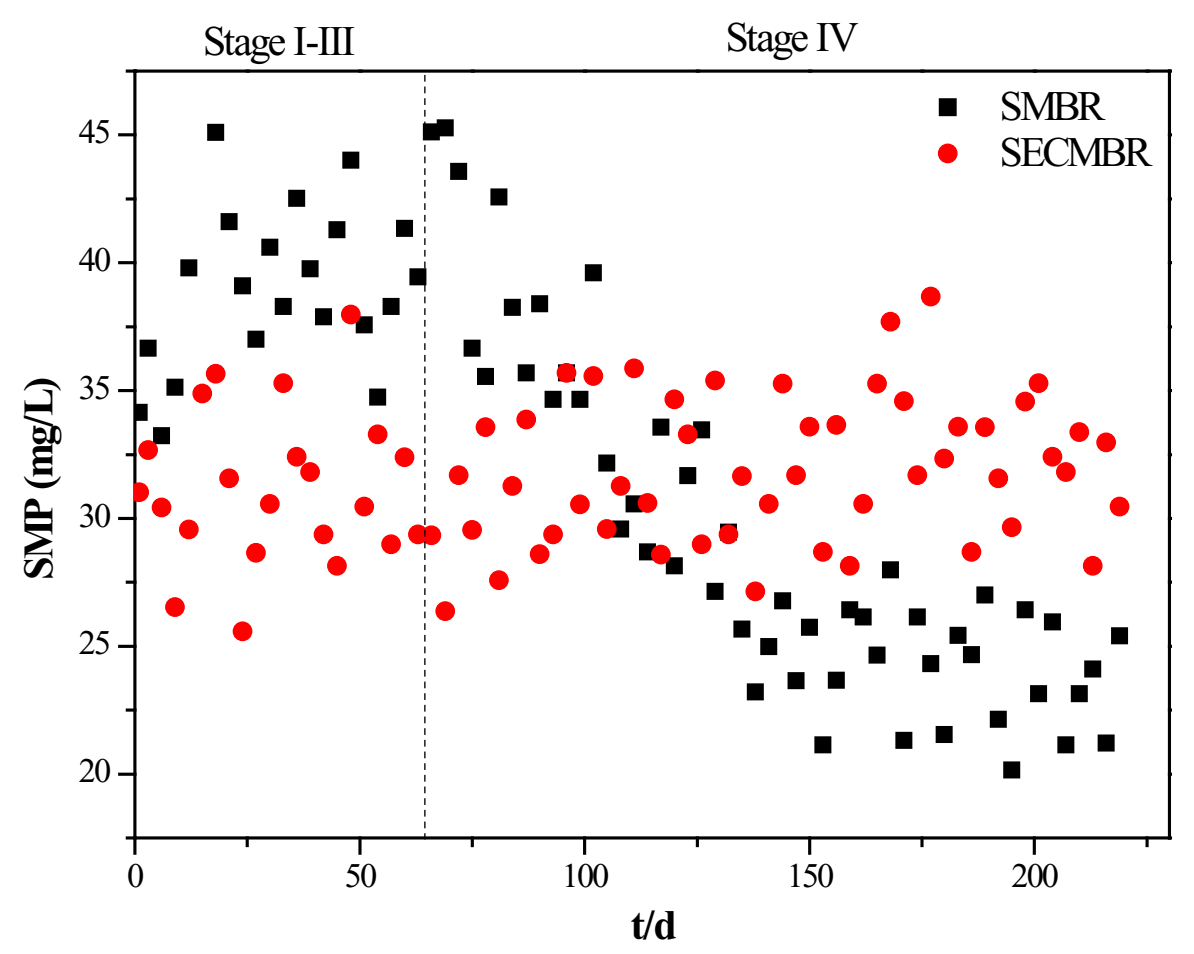

Fig. 4 Variations of EPSc (A) and SMPc (B) in the two MBRs during stable operation. 


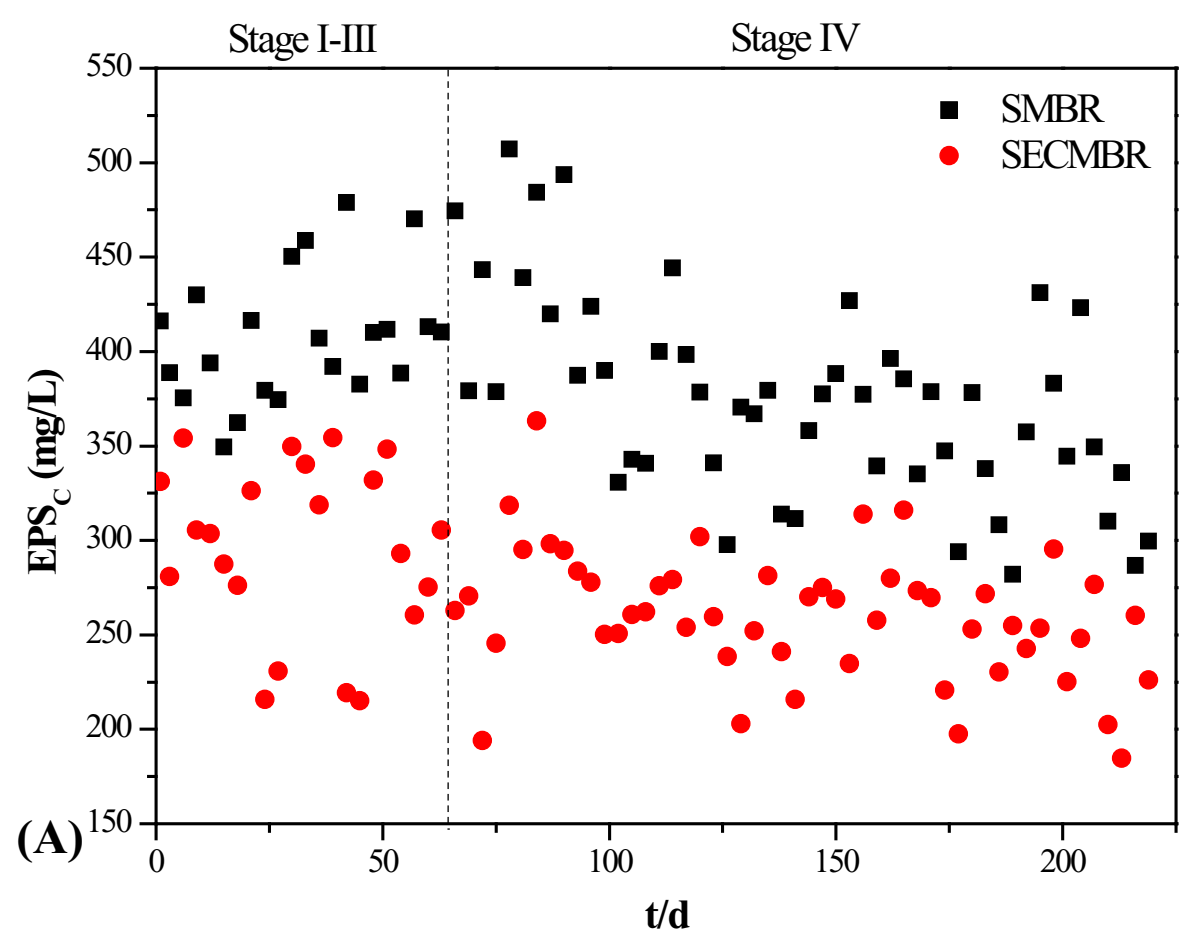

(B)

This article is protected by copyright. All rights reserved. 


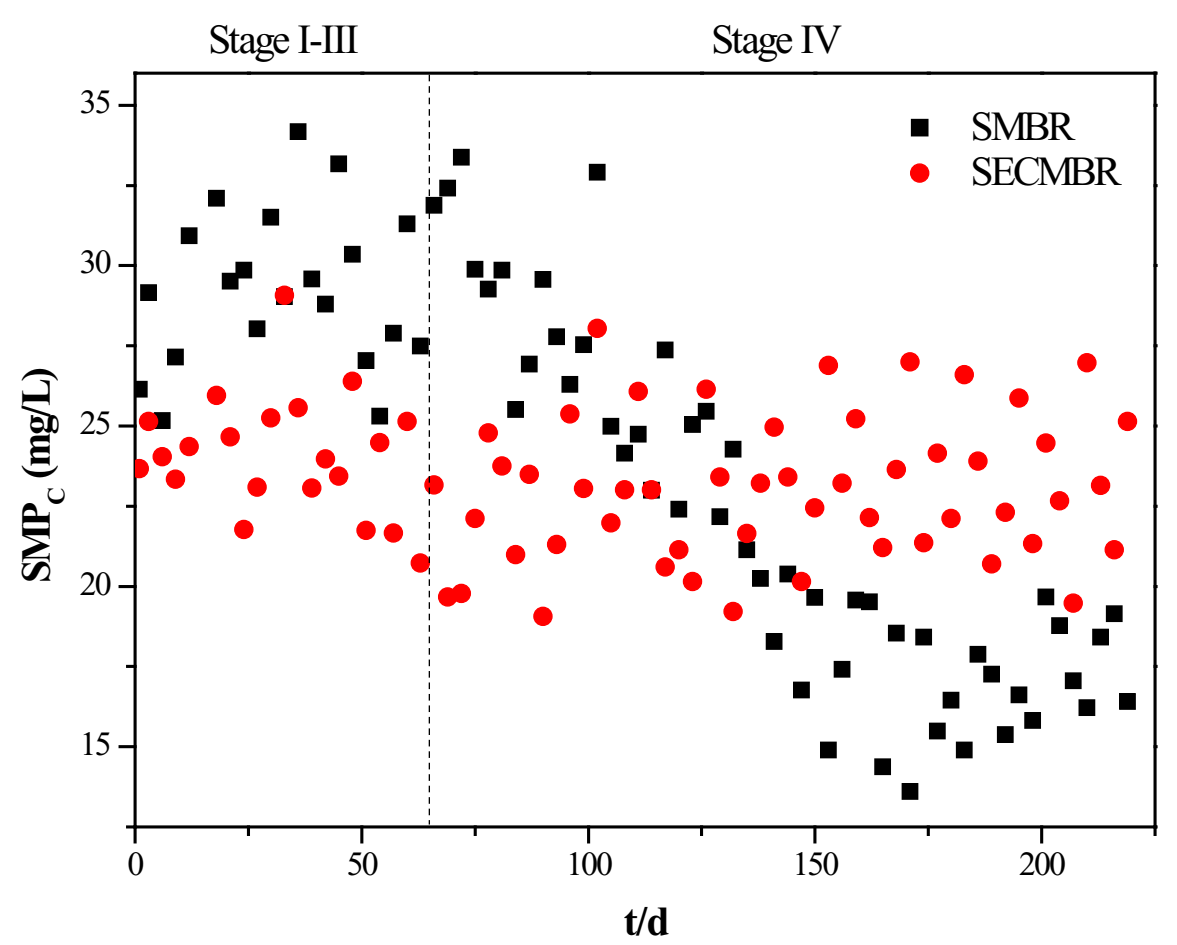

Fig. 5 MLVSS concentrations in the two MBRs during stable operation. 


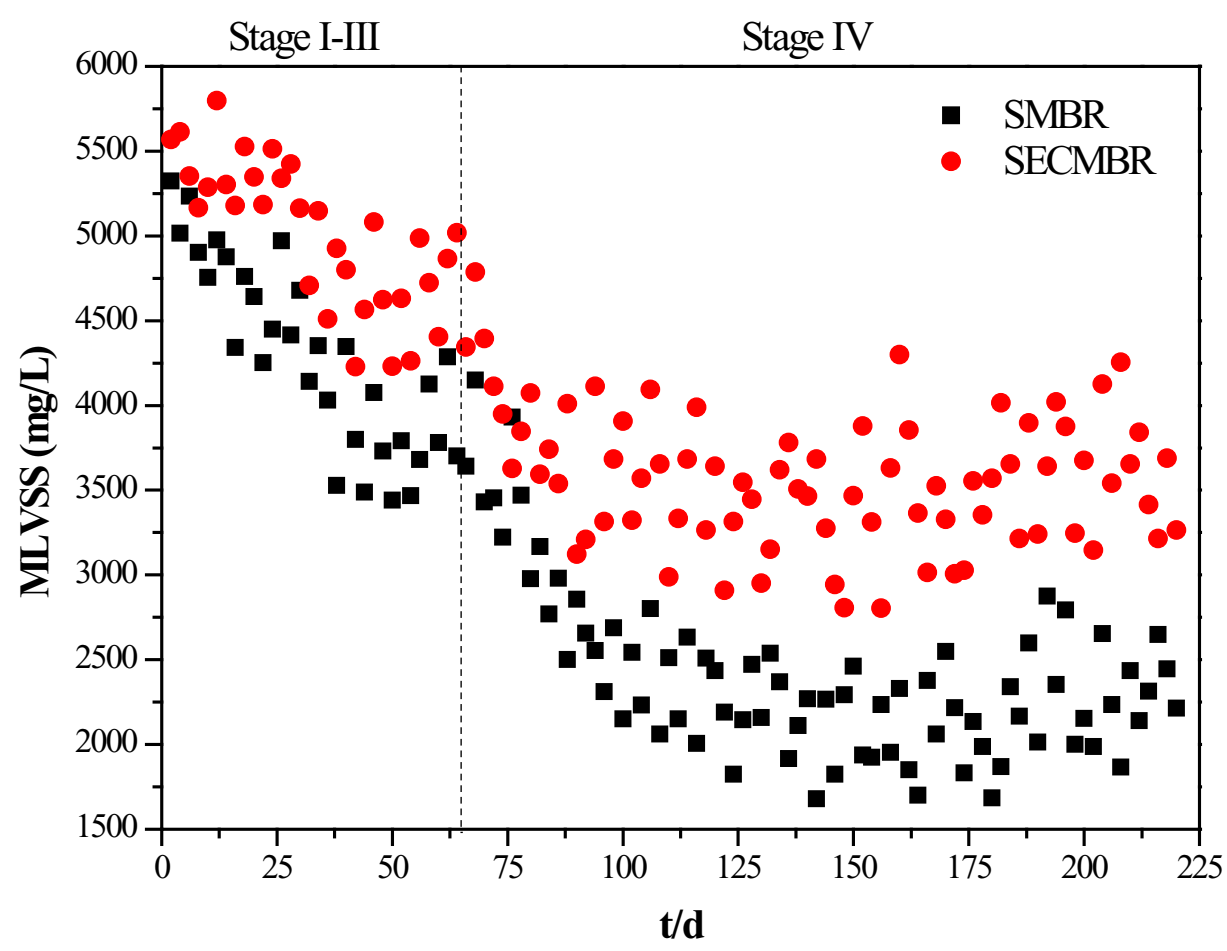

This article is protected by copyright. All rights reserved. 
Fig. 6 9 potentials in SMBR and SECMBR.

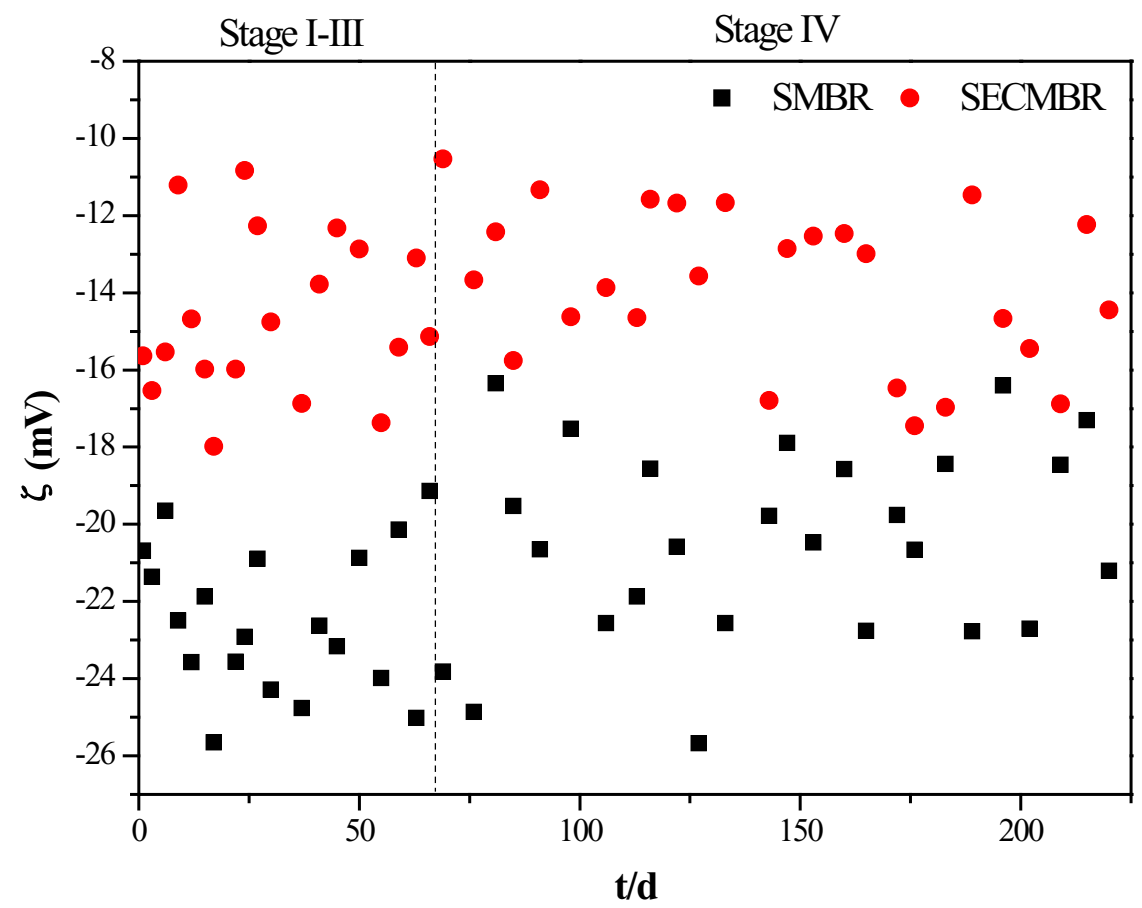

This article is protected by copyright. All rights reserved. 


\section{University Library}

\section{- M M I N E R VA A gateway to Melbourne's research publications}

Minerva Access is the Institutional Repository of The University of Melbourne

Author/s:

Qian, G;Ye, L;Li, L;Hu, X

Title:

Impact of electrocoagulation on membrane filtration resistance under different proportions of industrial wastewater

Date:

2018-11-01

Citation:

Qian, G., Ye, L., Li, L. \& Hu, X. (2018). Impact of electrocoagulation on membrane filtration resistance under different proportions of industrial wastewater. JOURNAL OF CHEMICAL TECHNOLOGY AND BIOTECHNOLOGY, 93 (11), pp.3160-3170. https://doi.org/10.1002/ jctb.5670.

Persistent Link:

http://hdl.handle.net/11343/284642 